[Bull. Agr. Chem. Soc. Japan, Vol. 21, No. 3, p. 166 172, 1957]

\title{
Column Chromatographic Fractionation of Apricot Emulsin*
}

\author{
By Akira BABA \\ Shiga Agricultural Collega Shiga Pref. Japan
}

Received November 26, 1956

\begin{abstract}
Crude emulsin of apricot (Prunas armenica) kernel was prepared by the method of tanninfractionation. It was then purified by a fractional ammonium sulfate precipitation. The purified enzyme was further fractioned by adsorbing the enzyme on a CM-cellulose column and eluting it with the diluted McIlvaine's buffer solution. By this chromatography, six peaks of activities of $\beta$-glucosidase and $\beta$-xylosidase were developed. From one component of these peaks, petal-like crystals were obtained. The fractions thus obtained by chromatographic fractionation and crystallization were found differ with regard to the ratio of the $\beta$-glucosidase activity to the $\beta$-xylosidase one.
\end{abstract}

The specificity, purification and chemical nature of $\beta$-glucosidase, $\beta$-galactosidase and $\beta$-xylosidase have been investigated for many years by various Workers1). The complete purification of these enzymes, however, has not yet been reported.

Thus, Miwa et al' ${ }^{2}$ have shown that the $\beta$-glucosidase, $\beta$-galactosidase and $\beta$-xylosidase of apricot emulsin can at least, be partially separated by fractional ammonium sulfate precipitation and other fractional method, although these enzymes are often considered to be the different activities of a single enzyme. For fungal enzyme, Morita3) has reported the separation of $\beta$-xylosidase from $\beta$-glucosidase, but has not succeeded in the isloation of $\beta$-xylosidase.

The homogeneity of the enzyme preparation thus reported, however, has not been shown by the above investigators, and the purification has usually been based on a relatively fractional method with several precipitating reagents.

* The present author uses the general term emulsin for ex pressing the enzyme system of apricor emulsin.

1) J.B. Sumner and K. Myrbäck, "The enzyme" Vol. 1, Part 1, Academic Press 1950, p. 584-630 (cited by Veibel).

2) T. Miwa and K. Tanaka. "Symposia on enzyme chemistry" (Japan), 1949, p. 19

3) Y. Morita, J. Biochem., 43. 7 (1956).
On the other hand, Jermyn ${ }^{4}$ employed the column chromatographic technique for examining the homogeneity of his stachybotrys atra $\beta$-glucosidase.

This paper deals with the chromatographic fractionation and crystallization of the enzyme in apricot emulsin.

\section{EXPERIMENTAL}

(1) Preparation of Crude Emulsin Ten kg of fresh apricot kernels was defatted with an oil expeller, and the cakes dried and finely powdered. By applying the purification method of Helferich et al. $\left.{ }^{5}\right), 75 \mathrm{~g}$ of crude emulsin was obtained from this powder. In this procedure, zinc sulfate treatment and tanninfractionation method were operated at room temperature $\left(15-20^{\circ} \mathrm{C}\right)$ but the acetone treatment was performed in an ice box to prevent the inactivation of enzyme. In the last step of this process the enzyme precipitate was washed with petroleum ether and dried under reduced pressure. The purity of the enzyme preparation in this stage was observed by the electrophoretic analysis under the conditions indicated in the foot column of Fig. 1, and the existence of four or more components were recognized. On the other hand, specific $\beta$-glucosidic activity designated

4) M.A. Jermyn, Australian J. Biol, Sci., 8, 541 (1955).

5) B. Helferich, S. Winkler, R. Gootz, O. Peters, und E. Günther, Z. pbysiol. chem. 208, 91 (1932). J.B. Sumner and K. Myrbäck, "The enzyme", Vol. 1, Part 1, Academic Press, 1950, p. 585 (cited by Veibel) 


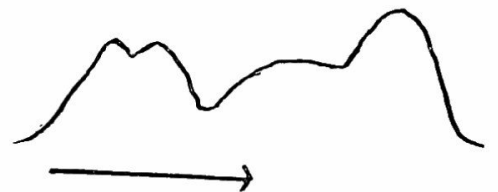

FIG. 1. Electrophoresis of Crude Apricot Emulsin (Hitachi electrophoretic apparatus)

Sample; after tannin-fractionation and dialysis: concn. of protein; $2 \%$ : buffer; $\Gamma / 2=0.05, \mathrm{pH} 4,8$ acetate buffer: time; 100 min.: tmp.: $5^{\circ} \mathrm{C}$

as per mg protein was determined throughout the purification process as shown in Table $I$.

(2) Preparation of Purified Emulsin. With the procedure as shown in Table I, further purification of crude emulsin was carried out. In this process, collodion casing was employed for the dialysis of enzyme solution, and it was found effective for the removal of the yellow color impurity. At the end of this purification process, the purity of this enzyme preparation was investigated by the electrophoretic analysis as shown in Fig. 2, and a slight separation

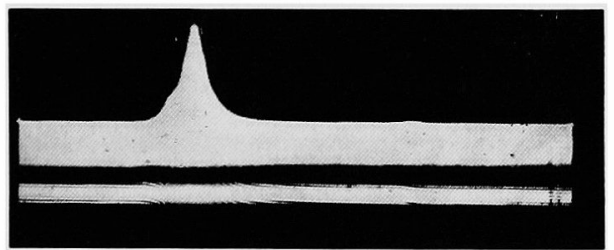

FIG. 2. Electrophoresis of Purified Apricot Emulsin (Spinco Model $\mathrm{H}$ electrophoretic apparatus)

Sample; after $\left(\mathrm{NH}_{4}\right)_{2} \mathrm{SO}_{4}$-fractionation, sp. act. 31 ( $\beta$-glucosidase): concn. of protein; $1.5 \%$ : buffer; $\Gamma / 2=0.05, \mathrm{pH} 4,8$ acetate buffer; time; 74 min.: temp.; $5^{\circ} \mathrm{C}$

of three or more components was observed although the preparative separation of these components by the electrophoretic apparatus was not accomplished. The over-all purification designated as the specific $\beta$ glucosidic activity was found to be approximately 300 -fold in this stage.

Further purification of the enzyme with ammonium sulfate was not successful. Therefore, the following column chromatographic fractionation of the enzyme was attempted.

(3) Chromatographic Fractionation of Purified

\section{Emulsin}

1. Preparation of cation-exchanging CM-cellu-

lose According to the briefly described precedure of Sober et al. ${ }^{6)}$, cation-exchanging CM-cellulose was prepared as follows: the mixture of $100 \mathrm{~g}$ cellulose powder (Toyo Roshi Co., Ltd.) and one liter of 15\% sodium hydroxide solution was heated on a boiling water bath for ten min.. After cooling, $20 \mathrm{~g}$ of monochloroacetic acid was added to the mixture and it was heated again for ten min.. The alkaline mixture was neutralyzed with glacial acetic acid and washed repeatedly with distilled water until the $\mathrm{pH}$ of the washings became 5.6.

2 . Test for adsorption of $\beta$-glucosidase on CMcellulose by batch-operation It could be shown that the $\beta$-glucosidase in the dialyzed solution was specifically adsorbed on CM-cellulose in the suitable $\mathrm{pH}$ (Fig. 3). In this test $5 \mathrm{ml}$ of the dialyzed enzyme

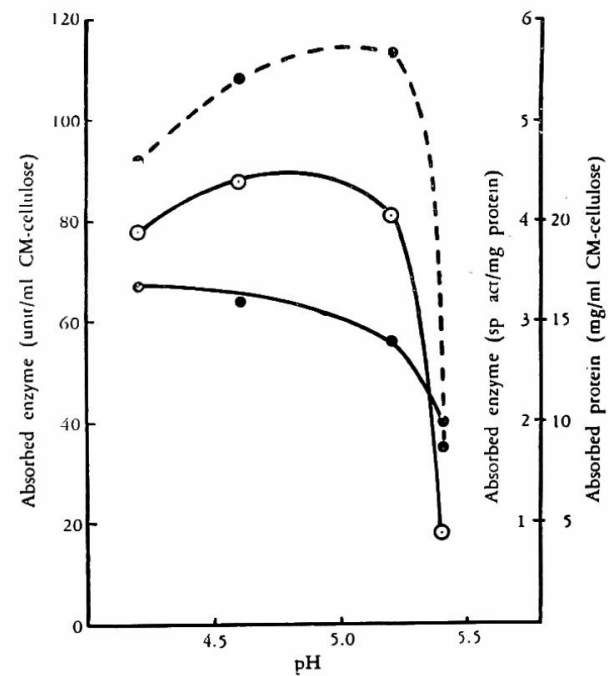

FIG. 3. Adsorption of $\beta$-Glucosidase on CM-Cellulose (Batch operation)

Sample; ap. act. 4 (B-glucosidase): CM-cellulose; $1.5 \mathrm{ml}$ (sediment-volume): buffer; 10 times diluted McIlvaine's buffer ( $0.02 \mathrm{M}$ sodium phosphate- $0.001 \mathrm{M}$ citric acid): room temp. $\left(30^{\prime} \mathrm{C}\right)-\odot-$ activity, $-\bullet-$ protein, - - - sp. act.

B-glucosidase activity was determined by the method of Sumner. 7) Protein was determined by the method of Gornall et a 18 )

solution (containing 185 units of $\beta$-glucosidase, sp. act. 4.0) was mixed with $2.5 \mathrm{ml}$ of the diluted McIlvaine's buffer solution $(0.02 \mathrm{M}$ sodium phosphate-0.001 M citric acid) previously adjusted to various $\mathrm{pH}$ values

6) H.A. Sober and E.A. Peterson, J. Am. Chem. Soc., 76, 1711 (1954).

7) J. B. Sumner and G. F. Somers, "Laboratory Experiment in Biological Chemistry" 1949 , p. 144.

8) A. G. Gornall, C. J. Bardawill and M. David. J. Biol., Chem. 177, 751 (1949) 
(4.0, 4.5, 5.0, 5.5). The buffered enzyme solutions were poured onto the CM-cellulose which had been sedimented in centrifuge tubes (sedimentary volume, $1.5 \mathrm{ml}$ ) and shaken immediately. After thirty minutes the adsorbents were centrifuged off. The quantities of protein and $\beta$-glucosidase activity units in these supernatant solutions were determined. From these values the amounts of adsorbed protein and enzyme were calculated. $\mathrm{pH}$ values of the supernatant solutions were also determined and the values were dotted in Fig. 3.

3. Preparation of column The above mentioned CM-cellulose was packed into the glass tube (diam. $1.45 \mathrm{~cm}$, height $50 \mathrm{~cm}$ CM-cellulose column) with distilled water, and it was washed with distilled water until the washing lost its turbidity. Since the volume of the CM-cellulose was slightly decreased by washing, the volume was made up to the height of $50 \mathrm{~cm}$. The packed CM-cellulose was buffered with $200 \mathrm{ml}$ of diluted McIlvaine's buffer solution (pH 4.8, $0.02 \mathrm{M}$ sodium phosphate-0.001 $\mathrm{M}$ citric acid).

4. Adsorption of enzyme on CM-cellulose column The purified enzyme was dialyzed against distilled water and buffered with the same volume of diluted Mcllvaine's buffer solution ( $\mathrm{pH} 4.8,0.02 \mathrm{M}$ sodium phosphate-0.001 M citric acid). This buffered enzyme solution $(12.5 \mathrm{ml}$, containing $100 \mathrm{mg}$ of protein, 3100 units of $\beta$-glucosidase) was poured onto the column.

5. Fractional elution and assay of enzyme activity As the eluent, diluted McIlvaine's buffer solutions adjusted to pH 4.8 and pH 8.0 (0.02 M sodium phosphate-0.001M citric acid) were prepared. The flask containing $200 \mathrm{ml}$ of the $\mathrm{pH} 4.8$ buffer solution was placed on a shelf, fitted in a height of $1.5 \mathrm{~m}$ from the upper end of the column, and connected to the column with a rubber tube. Then the buffer solution was continuously poured on to the colunm, and the $\mathrm{pH}$ of the buffer solution was slowly raised in steps from 4.8 to 7.0 by addition of the pH 8.0 buffer solution (when each $10 \mathrm{ml}$ of the buffer solution flowed out from the column, the same volume of the $\mathrm{pH} 8.0$ buffer solution was mixed into the flask). The effluent was collected in portions of $2 \mathrm{ml}$ each and $\beta$-glucosidase and $\beta$-xylosidase activities were estimated by the following procedure. The quantity of protein in each fraction was determined by the method of Lowry et $a l^{9}$. For the measurement of $\beta$-glucosidase activity, the reaction mixture was prepared by mixing with $0.5 \mathrm{ml}$ of $0.02 \mathrm{M}$ salicin solution (salicin was dissolved with $\mathrm{pH} 4.4,0.1 \mathrm{M}$ acetate buffer) and $0.04 \mathrm{ml}$ of enzyme solution. After the incubation of the mixture at $30^{\circ} \mathrm{C}$ for one min., $0.5 \mathrm{ml}$ of $0.1 \mathrm{~N}$ sodium hydroxide solution and $3 \mathrm{ml}$ of dinitrosalicylic sugar reagent ${ }^{10}$ were mixed successively, and the mixture was heated for five $\mathrm{min}$. in boiling water. The optical density of this solution was taken in the Coleman universal spectrophotometer. By this procedure of enzyme assay, the unit of enzyme activity was not determined but the relative $\beta$-glucosidase activity was estimated. The $\beta$-glucosidase activity was measured by the same procedure except that O-cresyl $\beta$-D-xyloside (m.p. 161-2 ${ }^{\circ}$ ) was employed as the substrate and the time of incubation was lengthened to thirty min..

By this column chromatography six $(a, b, c, d, e$ and $f)$ peaks of activities of $\beta$-glucosidase and $\beta$ xylosidase, respectively were observed as shown in Fig. 4, and the distinct shift of the ratios of $\beta$-glucosidase to $\beta$-xylosidase in each peak was recognized. The clear separation of $\beta$-glucosidase from $\beta$-xylosidase, however, did not occur.

(4) Crystallization As shown in Fig. 4 the effluent fractions were divided into six components ( $a, b, c, d, e$ and f), and each component was treated to crystallize with the procedure summarized in Table I.

In this way, petal-like crystals depositted from the component (a) and they were accompanied with a considerable quantity of amorphous matter. Most of the amorphous matter was separated from the crystals by centrifuging at low velocity of rotation. Fig. 5 shows the crystals from component (a). In other components no definite crystalline substance was found.

Recrystallization of the enzyme was not attempted, because of the insufficient amount of the crystals for this purpose.

(5) Enzyme Activities of Crystalline Preparation One drop of the crystalline suspension was dissolved with $10 \mathrm{ml}$ of distilled water, and the $\beta$ glucosidase and $\beta$-xylosidase activities of one $\mathrm{ml}$ of this enzyme solution were measured by the procedure above mentioned. On the other hand, a small amount of the tannin-fractionated emulsin powder ("crude emulsin" in Table I) was dissolved with distilled water, and the insoluble matter was centrifuged out. This crude enzyme solution was diluted

9) O.H. Lowry, N.J. Rosebrough, A.L. Fart, R. J. Randall, J. Biol. Chem. 193, 265 (1951).

(10) J.B. Sumner, J. Biol. Chem. 65, 393 (1925). 

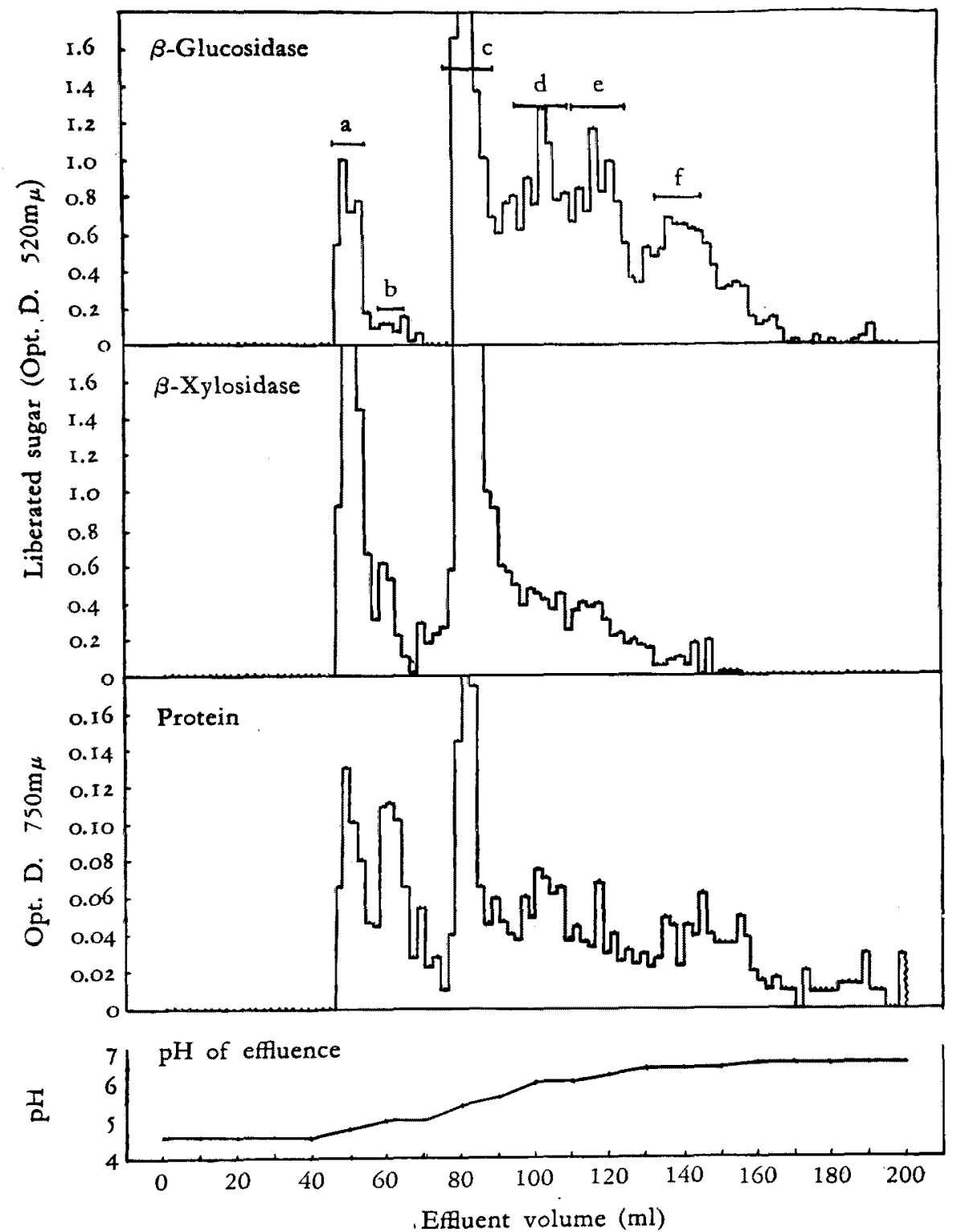

FIG. 4. Chromatography of Purified Apricot Emulsin.

Sample; $100 \mathrm{mg}$ protein, sp. act. 31 (B-glucosidase) : column; $50 \times 1.45 \mathrm{~cm}$ (CM-cellulose): buffer for elution; pH 4.8-7.0 ( $\mathrm{pH} 8.0,10$ times diluted Mcllvaine buffer was added slowly to $\mathrm{pH} 4.8,10$ times dilured Mcllvaine buffer): effluenc rate; 3-10ml/hr.: temp.; $20-22^{\prime}$ C: recovery of total protein; $80 \%$.

with distelled water until one $\mathrm{ml}$ of this solution contains the corresponding amount of $\beta$-glucosidase activity to the above crystalline enzyme solution.
The $\beta$-xylosidase activity of this crude enzyme solution was measured, and compared with that of the crystalline enzyme solution. From this experiment a 


\section{TABIE I. PURIFICATION AND Fractionation of APRICOT EMUlsin}

Powder of apricot secds; sp. act. 0.1 (extd. with distd. $\mathrm{H}_{2} \mathrm{O}$ )

$\downarrow$

Tannin-fractionation; Helferich's merhods)

$\downarrow$

Crude emulsin: Enzyme powder ; sog, ext. (1000ml distd. $\mathrm{H}_{2} \mathrm{O}$ )

$\downarrow$

Extract; filter with the aid of animal charcoal

Extrai

Filtrate; sp. act. 1, yield 100\%, dialyze against distd. $\mathrm{H}_{2} \mathrm{O}$ (collodion casing, 2 days)

$\downarrow$

Dialyzate; flter with the aid of animal charcoal

$\downarrow$

Filtrate; sp. act. 4, yield $91 \%$

$\downarrow$

Ist $\left(\mathrm{NH}_{4}\right)_{2} \mathrm{SO}_{4}$-fractionation; 0.48-0.7 sat, $\mathrm{pH} 4.8,30 \mathrm{C}$

$\downarrow$

Precipitate; dissolve (minimum distd. $\mathrm{H}_{2} \mathrm{O}$ ), dialyze against distd. $\mathrm{H}_{2} \mathrm{O}$, (collodion casing, 2 days)

$\downarrow$

Dialyzate; filter with the aid of animal charcoal

$\downarrow$

Filtrate; sp. act. 6 , yield $64 \%$

$\downarrow$

2nd $\left(\mathrm{NH}_{4}\right)_{2} \mathrm{SO}_{4}$-fractionation; $0.48-0.65$ sat. $\mathrm{pH} 4.8,30 \mathrm{C}$ $\downarrow$

Precipitate; dissolve (minimum distd. $\mathrm{H}_{2} \mathrm{O}$ ), dialyze against distd. $\mathrm{H}_{2} \mathrm{O}$ (collodion casing) $\downarrow$

Dialyzate; centrifuge, 4000 r.p. m., $20 \mathrm{~min}$.

$\downarrow$

Supernatant ; sp. act. 23 , yield $17 \%$

$\downarrow$

3rd $\left(\mathrm{NH}_{4}\right)_{2} \mathrm{SO}_{4}$-fractionation; $0.48-0.6$ sat. $\mathrm{pH} 4.8,30 \mathrm{C}$

$\downarrow$

Precipitate; dissolved (minimum distd. $\mathrm{H}_{2} \mathrm{O}$ ), dialyze against distd. $\mathrm{H}_{2} \mathrm{O}$ (collodion casing, 1 day) $\downarrow$

Dialyzate; centrifuge 4000 r. p. m. $20 \mathrm{~min}$.

$\downarrow$

Supernatant

$\downarrow$

4 th $\left(\mathrm{NH}_{4}\right)_{2} \mathrm{SO}_{4}$-fractionation; $0.5-0.6$ sat. $\mathrm{pH} 4.8,30 \mathrm{C}$

$\downarrow$

Precipitate; dissolve (minimum distd. $\mathrm{H}_{2} \mathrm{O}$ ), dialyze against distd. $\mathrm{H}_{2} \mathrm{O}$, (collodion casing, 1 day) $\downarrow$

Dialyzate; sp. acr. 31, yield $12 \%$ add solid $\left(\mathrm{NH}_{4}\right)_{2} \mathrm{SO}_{4}(0.7$ sat $)$ Purified emulsin : Precipit

Dialyzate<smiles>[AlH2]</smiles>

Chromatographic fractionation

$\downarrow$

Enzyme solution; (6 components), dialyze against $400 \mathrm{ml}$ of 0.7 sar. $\left(\mathrm{NH}_{4}\right)_{2} \mathrm{SO}_{4}$, outer soln change 3 times, $\downarrow$ centrifuge 7000 r. p. m. 15 min.

Precipitate; dissolve (minimum $\mathrm{H}_{2} \mathrm{O}$ ), dialyze against distd. $\mathrm{H}_{2} \mathrm{O}$ (collodion casing, 1 day) $\downarrow$

Dialyzate; centrifuge 4000 r. p. m. $10 \mathrm{~min}$. 
(Continuation of TABLE I)

Supernatant; add solid $\mathrm{Na}_{2} \mathrm{SO}_{4}$ (0.5 sat), add small amount of sat. $\left(\mathrm{NH}_{4}\right)_{2} \mathrm{SO}_{4}$ $\downarrow$

Slight turbid solution; add minimum amount of distd. $\mathrm{H}_{2} \mathrm{O}$ until the white precipitate disapear in about $\downarrow 30 \mathrm{~min}$.

Solution; slowly condenced with silica gel (in refrigerator, 5 days) $\downarrow$

Crude crystal; (appear from (a) component only), add 10 times vol. of 0.7 sat. $\left(\mathrm{NH}_{4}\right)_{2} \mathrm{SO}_{4}$, centrifuge 1000 $\downarrow$ r.p.m. 2-3 mi 1. (repeat 3 times), microscopic examination

Precipitate (purified crystal)

$\beta$-glucosidase activity was determined by the method of Sumner ${ }^{7}$ )

Protein was determined by the method of Gornall et al ${ }^{8}$ ) or Lowry et al9)

Specific activity was designated as $\beta$-glucosidase units per $\mathrm{mg}$ protein.

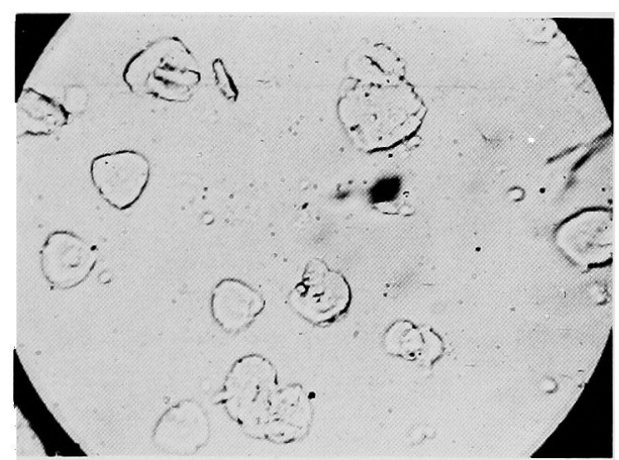

FIG. 5. Crystalls from Apricot Emulsin. $\times 600$

relatively strong $\beta$-xylosidase activity was proved in the crystalline preparation as shown in Fig. 6. However, the definite nature of the crystals still remains unsolved.

\section{DISCUSSION}

As mentioned above, crude apricot kernel emulsin was purified by the fractional ammonium sulfate precipitation with regard to the specific $\beta$-glucosidase activity as a criterion, but the complete purification of the enzyme by this procedure resulted in fail. The preparative separation of the components with the aid of Spinco Model H electrophoretic apparatus was not accomplished because of their extremely close mobilities. From the view point of these facts it is interpreted that apricot emulsin contains some components which have closely resembled physicochemical properties.

When the purified enzyme preparation was

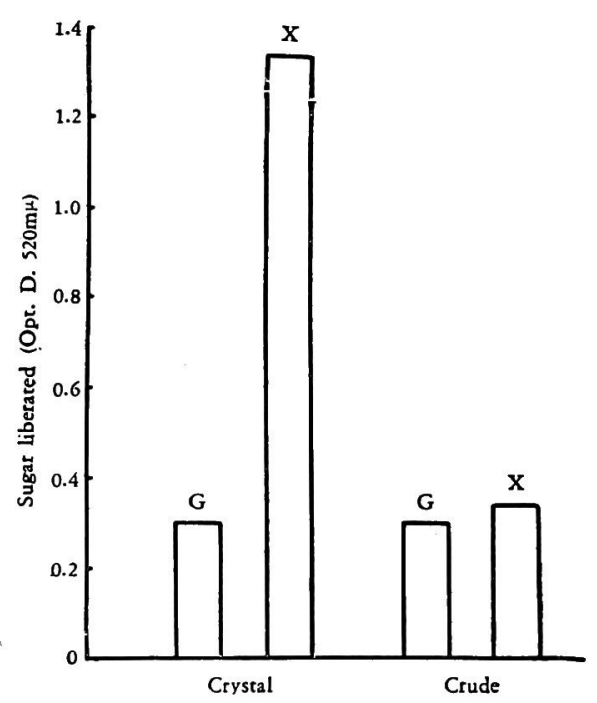

FIG. 6. Comparison of the Activites of $\beta$-Glucosidase and $\beta$-Xylosidase with Crude and Crystallized Preparation.

crude enzyme; after tannin-fractionation: G; $\beta$-glucosidase activity: $X ; \beta$-xylosidase activity. Enzyme activities were measured with the same procedure in the case of column chromatography

chromatographed with CM-cellulose column, it was apparently separated in six components, and the crystalline substance was obtained from component (a) although the other components were not crystallized. Therefore, the chromatographic fractionation seemed to be effective for the separation of the crystalline substance.

As to the question whether $\beta$-glucosidase and $\beta$-xylosidase of apricot emulsin is com- 
pletly separated, the author could not isolate any perfectly single enzyme in this study, but the distinct shift of the ratio of $\beta$-glucosidase to $\beta$-xylosidase was effected by the column chromatography. The separation of the two enzymes was not complete even after crystallization. However, it is noteworthy that the crystals indicated a relatively strong $\beta$-xylosidase activity.

On the other hand six peaks of activities of $\beta$-glucosidase and $\beta$-xylosidase were de- veloped by the column chromatography, but the difference in these fractions has not yet been determined.

The author wishes to acknowledge his indebtness to Prof. Z. Nikuni for his valuable advice. He also wishes to thank Prof. T. Miwa for kindly furnishing him with O-cresyl $\beta$-xyloside, and Dr. B. Maruo for his helpful guidance in the electrophoretic analysis. 